\title{
INTEGRATED ASSESSMENT OF THE CREDIT POLICY EFFICIENCY
}

\author{
Lyubov Vanchukhina ${ }^{1}$, Tatyana Leybert ${ }^{2}$, Yulia Rudneva ${ }^{3}$, Nelli Galeeva ${ }^{4}$, \\ Anastasia Rogacheva ${ }^{5}$, Elvira Khalikova ${ }^{6}$, Giedrius Ciras $^{7}$ \\ ${ }^{1-6}$ Department of Accounting and audit, Institute of Oil and Gas Business, Ufa State Petroleum \\ Technological University, 450062, 1 Kosmonavtov Street, Ufa, Russian Federation \\ ${ }^{7}$ Department of Business Technologies and Entrepreneurship, Faculty of Business Management, \\ Vilnius Gediminas Technical University, Sauletekio al. 11, 10223 Vilnius

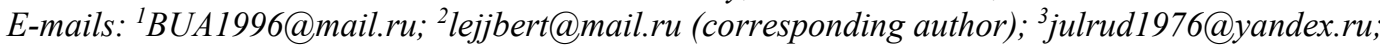 \\ 4nelli-galeeva@yandex.ru; ${ }^{5 i z a b o @ b k . r u ; ~}{ }^{6} y d a c h a 6 @ y a n d e x . r u ;{ }^{7}$ giedrius.cyras@vgtu.lt
}

\begin{abstract}
The credit policy is a basis of receivables management. The competent combination of its parameters allows to increase a greater effect of commercial crediting applying by the company. The purpose of this study is to develop a methodology for assessing the effectiveness of various credit policy types: conservative, moderate and aggressive. The comparative analysis of three methods of assessment of the credit policy efficiency is carried out in the article: The NPV analysis, the valuation model based on the average daily margin and the model for assessing the impact of changes in the company's credit policy. As a result, the technique of the full and quick estimate methods of the credit policy efficiency, including calculation of individual, intermediate and integrated indicators are offered. The method is based on three groups of the indicators, reflecting the company credit policy efficiency in the following directions: quality receivables management, receivables costs maintenance and influence on a company financial condition. The influence of each of the indicator and indicators groups when using different credit policy's types were proved in the article and that allowed to transform them to a general integrated indicator. This technique allows to estimate in a complex and objectively efficiency of the credit policy operating in the company.
\end{abstract}

Keywords: receivables, credit policy, conservative, aggressive and moderate types of credit policy, credit policy efficiency, cost of maintaining receivables, integrated credit policy efficiency assessment.

JEL Classification: E51, L21.

\section{Introduction}

At the present stage of the economic relations development, a large proportion of current assets for many Russian companies always account for receivables. It arises from the provision of commercial credit, i.e. at realization of production with granting of a delay of payment. As a result, there is an increase in sales and revenue growth. The reverse side of this process is the diversion of capital and a decrease in the solvency of the firm. Therefore, the objective of credit policy is to ensure an optimal balance of advantages and disadvantages of commercial lending.

The credit policy that achieves this goal can be considered effective. Accordingly, the effectiveness of credit policy is determined by the value of an additional positive result arising from investing in receivables.

When making a managerial decision with respect to credit policy, three main elements can be varied:
- duration of the time period for which the buyer is granted a deferred payment;

- a set of discounts for early or timely payment and late fees;

- the time period while the proposed discounts apply.

In the course of implementing the chosen credit policy, the company is changing its financial and economic performance, in different directions. For example, a decrease in receivables may be accompanied by a decrease in sales, and vice versa. Therefore, it is necessary to develop an approach to a comprehensive assessment of the effectiveness of credit policy, taking into account the diversity of consequences of its impact. In addition, the formation of financial, incl. credit, policy should take into account the enterprise development strategy and on the basis of functional analysis (Tunčikienė \& Drejeris, 2015).

However, before assessing the various indicators that characterize one or another aspect of the credit policy effectiveness, it is necessary to 
diagnose the external and internal environment of the company's functioning. This will determine the credit policy type (conservative, aggressive or moderate) appropriate to the current situation. In paper (Mityushnikova, Rudneva, \& Gareeva, 2017) results of research of three credit policy types are presented and the description of the external and internal environment conditions favorable for their application is made.

Each of the credit policy types has its own priorities, which must be taken into account when forming an effectiveness indicators system.

Thus, there is the problem of forming an integrated system for assessing the consequences of implementing a particular credit policy, taking into account the specific features of its individual types.

\section{Analysis of methods for assessing the credit policy effectiveness}

The selected combination of credit policy elements has a significant impact on indicators of activity of the enterprise, which analysis is submitted in the works of economists from Russia and other countries (Arutyunyan \& Borisov, 2015; Dincă, M. S. \& Dincă, G., 2013; Gerasimova, 2012; Huang \& Goyal, 2007; Kim, Hwang, \& Shinn, 1995; Kuznetsova, 2014; Li, Skouri, Teng, \& Yang, 2018; Lipchenko, 2014; MartínezSola, García-Teruel, \& Martínez-Solano, 2013; Tavis, 1970; Volnin, 2011; Zimin, 2014; Zotkov, 2012). Ultimately, the granted deferral duration and the amount of discounts and penalties are reflected both in financial results and in the organization value. Let's consider the basic methods of the credit policy efficiency estimation, applied today:

- NPV-analysis;

- valuation model based on the average daily margin;

- a model for assessing the impact of changes in the company's credit policy.

NPV analysis. It considers receivables as an investment, which brings a certain income in the future. Accordingly, as a result of discounting the outgoing and incoming flows, an additional useful effect is estimated when the elements of the credit policy change.

As inflows, the receipt of proceeds from the sale of goods is considered. Outflows are the cost and debt servicing costs, which also include additional costs to raise additional funds to finance current activities in a delayed payment environment.
The main problem of this approach is the complexity and insufficient objectivity of forecasting future cash flows. There are also many disputes in justifying the discount rate.

The valuation model is based on the average daily marginal profit. According to this model, it is considered that a positive effect is achieved with an increase in the ratio of the marginal profit amount to the receivables turnover period. This approach is fairly simple to apply, but takes into account only one indicator.

Model for assessing the impact of changes in the company's credit policy. It is based on the assertion that the main objective of changing the enterprise credit policy is to maximize net cash flow and to minimize credit risk.

To assess the impact of changes in the organization's credit policy, this model assumes a comparison of the company's net cash position, which is planned to be received after a certain time interval after the credit policy was changed, and the current cash flow that the company has at the moment. Effective is considered a change in the credit policy, under which there is an increase in the company's cash flow. An analysis of this technique is presented in paper (Lukyanova \& Nikulin, 2008). The problem of cost estimation, i.e. negative cash flow, are devoted to the work of the American professor K. Duft (Duft, 2006).

There are two this model drawbacks:

- subjectivity of forecasts positive, negative and, as a result, pure cash flows;

- evaluation of effectiveness only after a certain period of the changed credit policy validity without the possibility of carrying out an intermediate analysis.

To eliminate the drawbacks identified in the models studied, an integrated methodology for assessing the credit policy effectiveness was proposed in this paper.

The actual problems of assessing the enterprise credit policy effectiveness are devoted by (Białek-Jaworska \& Nehrebecka, 2016; Isachenko, 2014; Mahata, P. \& Mahata, G. C., 2014; Nechaev \& Gerasimova, 2013; Nikolaev, 2015; Oh \& Kim, 2016; Prudnikov, 2014; Sidorov, 2013; Trenev, 2015; Volostnova, 2015) modern economists, who studied the effect of commercial lending on the enterprise productivity.

Let's allocate the parameters that characterize the corporation credit policy effectiveness: sales and revenue growth; debt service costs reduction; financial results improvement; financial condition improvement. 
On the basis of the above-mentioned effects, the of the credit policy effectiveness indicators can be combined into three groups.

The first group: a group of the balance sheet indicators, characterizing the amount and structure of the enterprise's receivables.

This group combines indicators that allow to conduct a factor analysis of accounts receivable, which includes:

- an estimation of the amount of organizations accounts receivable and its dynamics in the previous period;

- definition of the average collection period for receivables and its turnover quantity in the period under review;

- an estimate of the accounts receivable composition for particular of its "age groups", i.e. by the stipulated terms of its collection;

- analysis of the overdue accounts receivable composition with the doubtful and bad debts allocation. The results of the analysis are used in the process of subsequent development of individual company credit policy parameters (Galaktionova, 2015).

The second group: indicators related to the receivables servicing. When implementing a credit policy, it is necessary to take into account the fact that the credit submitting increases sales, but it is accompanied by an increase in costs, and at some point these costs can exceed the additional profit from increased sales. Therefore, in managing accounts receivable, it is necessary to assess the current credit policy effectiveness in terms of exceeding the revenues from its sale over the servicing accounts receivable costs (Kisileva, 2013).

Additional profit in the credit policy implementation arises:

- from the increase in sales (revenue);

- from the unit costs reduction (production growth contributes to a decrease in the fixed costs per unit of output).

However, by granting a deferred payment to the buyer, the enterprise will incur costs associated with the increase in accounts receivable (Sokolova, 2014):

- costs associated with financing the emerging requirement for additional working capital;

- expenses for management of receivables (personnel, machinery, telephone, etc.);

- losses related to the nonpayment of receivables.
It should be noted that in addition to direct losses due to inflationary processes, the supplier organization incurs losses that are related to the need for debt servicing, as well as to the lost profit from the possible use of temporarily free cash. For influencing on the consumers the development of penalties for late payment may be considered. Increase in terms of payment is equivalent to reducing the price of products, services, and work. The increase in sales promotes the rise of the purchased material values.

The third group: the indicators that affect the financial condition of the enterprise.

As an important element of the company's current assets, accounts receivable has a significant impact on various financial indicators of the enterprise: turnover and profitability, liquidity and responsibility, financial and market stability, the operational and financial cycle duration.

In this indicators group we will include indicators, which results from the receivables value. Short-term accounts receivable, which arises while corporation product selling on the terms of a deferred payment, refers to quick-selling assets and its value depends on the value of liquidity ratios. On the one hand, the higher the accounts receivable, the higher the liquidity ratios. On the other hand, an enterprise cannot always fully receive accounts receivable, which is used in calculating these coefficients.

The receivable repaid by buyers can be directed by the corporation to increase funds, or to repay loans. Thus, the value of accounts receivable has an impact on such indicators as the recoverability of cash, as well as accounts payable (Aristarkhova, 2016).

The credit policy is effective if the additional operational profit received by the enterprise from the increase in the sales of products on credit exceeds the additional operating expenses of the organization in servicing the receivables and the amount of losses of funds invested in receivables due to insolvency buyers (Nikolaev, 2012; Sanovich, 2013).

\section{Development of an indicators system for assessing the corporate credit policy effectiveness}

To develop a model for assessing the company's credit policy effectiveness, we select the most informative, in our opinion, indicators. We propose to form two indicator systems for assessing the credit policy effectiveness: 
- an indicator system that allows an overall effectiveness evaluation analysis, based on a set of indicators selected from each of the three groups examined;

- an indicator system, allowing to rapid analysis based on the selection of one, the most informative indicator from the three groups of coefficients considered.

In proposed methods the system of indicators to conduct a full analysis of the corporation credit policy effectiveness was developed.

For formation of model of the corporation credit policy efficiency assessment we will use the indicators which are in a complex characterizing work of the company with receivables. For this purpose we will select the most informative, from the point of view of the corporation credit policy efficiency characteristic, indicators from the following groups:

- the enterprise receivables management quality indicators;

- the indicators connected with service of receivables;

- the indicators reflecting influence on the enterprise financial condition.

From the indicators group of receivables quality management five indicators that give the most information on efficiency of the work organization with corporation contractors on the terms of a payment delay, it have been selected:

1. Receivables turnover coefficient: the coefficient allows to measure efficiency of work with contractors regarding receivables return / repayment and also characterizes the company policy for product sales on the terms of a payment delay. We will conditionally designate this coefficient of $K_{1}$.

2. Growth rate of receivables $\left(K_{2}\right)$ : allows to analyse the contractors crediting policy type chosen by the enterprise, to assess the corporation's payments collection efficiency, the commercial credit conditions optimality.

3. Coefficient of a ratio of the company receivables 'average size and the money invested in receivables possible limit $\left(K_{3}\right)$. Inclusion of this coefficient in the developed credit policy efficiency assessment model is based on that it is also possible to determine what credit policy type the enterprise is focused.

4. Uncollectible debt proportion as a part of debit $\left(K_{4}\right)$ : shows efficiency of work with contractors, characterizes the enterprise contractors solvency standards assessment effectiveness system, actions for collecting the stitched debt from debtors.
5. Receivables and payables ratio coefficient $\left(K_{5}\right)$ : the indicator characterizes influence of receivables management policy on financial stability of corporation.

Excess of receivables over payables demonstrates inefficiency of the enterprise credit policy, about derivation of funds from a production turn and in the long term can result in of proceeds from loans and borrowings at bank for ensuring the current company activity. However considerable excess of accounts payable over debit can create threat of corporation financial stability.

From the indicators group connected with service of receivables we have selected three indicators giving the greatest information on expenses which the enterprise is forced to bear owing to product sales on the terms of a payment delay:

1. Overdue receivables coefficient $\left(K_{6}\right)$ : the indicator characterizes the realized corporation credit policy efficiency of regarding work with contractors of the enterprise for money return for the goods provided to them on credit. Dynamics of this indicator calculated for a certain period helps to define efficiency of actives on debt return.

2. Current assets derivation in receivables coefficient $\left(K_{7}\right)$ : the indicator characterizes the credit policy type realized by company. Rise of receivables share testifies to the company's soft credit policy (increase in term and size of the granted commercial loan, the discount high size for early payment of the shipped production, reduction of requirements to production buyers' solvency). Rise of this indicator is negative as says that the share of current assets distracts is increasing from economic circulation.

3. Coefficient of a ratio of the actual and planned funds, invested in receivables $\left(K_{8}\right)$.

From the indicators group reflecting influence on the enterprise financial condition we will also select the most informative indicators:

1. Urgent liquidity coefficient $\left(K_{9}\right)$ : allows to estimate a possibility of repayment of the current obligations of the company when her situation becomes critical. I.e. the coefficient of urgent liquidity expresses solvency in the short term.

2. Current liquidity coefficient $\left(K_{10}\right)$ : shows ability of the company to repay the current (shortterm) obligations at the expense of only current assets. Receivables size and also the chosen credit policy type directly influences this indicator value.

3 . Growth rate of sales proceeds $\left(K_{11}\right)$ : shows chosen corporation credit policy efficiency and effectiveness. The soft credit policy type is focused on increase in sales volume on credit and conse- 
quently also on sales volume growth; severe conditions of contractors crediting lead to decrease in amount of money, invested in receivables and consequently also the revenue growth rate may be slowed down.

4. Coefficient of sales profitability $\left(K_{12}\right)$ : estimates the most important aspect of the enterprise activity - the main production realization. The enterprise's choice of one or another credit policy type influences directly total revenue, t.i. the credit policy mitigation leads to increase in product sales volumes on credit, to gain of revenue; severe crediting conditions promote decrease in product sales volumes and accordingly to revenue size. Thus, the sales profitability indicator reflects the chosen by the enterprise credit policy efficiency, its influence intensity on such major indicators of the enterprise activity as sales income and profit.

5. Funds turnover coefficient $\left(K_{13}\right)$ : the intensity of receivables return exerts impact on the size of money on accounts and in cash desk of the enterprise, and respectively, also on the speed of funds circulation.

6. Coefficient of cash to sales ratio $\left(K_{14}\right)$ : in the present in many enterprises charge of income and money receipt on this income account happens to a considerable separation in time. That is the reason of growth of receivables. Calculation of this indicator is necessary from the point of view of growth / decrease in size of receivables comparison to growth/decrease in revenue.

7. Payables turnover coefficient $\left(K_{15}\right)$ : is estimated in conjunction with receivables turnover. This indicator enables to estimate efficiency of work with suppliers and contractors, how fast the corporation can pay off according to obligations and also as debts from debtors are quickly repaid. The situation when the receivables turnover is higher than payables' one is favorable for the enterprise.

We will develop the indicators system for carrying out the express analysis of corporation's credit policy efficiency assessment.

From each of the considered three indicators groups characterizing quality, cost of receivables maintenance, its influence on corporation's financial results we have selected on one of the most informative coefficient from our point of view:

- from the first indicators group - receivables turnover coefficient $\left(K_{1}\right)$;

- from the second indicators group - coefficient of a ratio of the actual and planned amount of money, invested in receivables $\left(K_{8}\right)$;

- from the third indicators group - growth rate of revenue $\left(K_{11}\right)$.
For the purpose of obtaining more exact, correct results for calculation of these indicators it is recommended to use the consolidated statements of group of companies. Applying of this corporations' reporting type is based on that income, expenses, property and obligations of the parent company and the enterprises controlled by him are presented in this reporting as income, expenses, property and obligations of the uniform enterprise, i.e. in particular if to analyse receivables, then its size will be corrected at a size of the mutual debts (creditor and debit) which are formed during of the parent and affiliated companies activity.

Thus, 15 indicators for carrying out the full analysis of credit policy efficiency assessment, and 3 indicators - for the express analysis - have been selected for proposed methods.

\section{Development of indicators integrated system for corporation credit policy efficiency assessment}

For formation the corporation credit policy efficiency integrated indicator model the authorities have been appropriated to each indicators group and also to each indicator included into a certain group. The authorities were appointed based on the authors' expert opinion.

We accepted that the total authorities' value for each indicators group and also all groups, is 1 . We distribute authorities for each indicator.

From the first group indicators we appropriated the largest authority to receivables turnover coefficient $\left(K_{1}\right)-0.3$. Assignment of the greatest importance to this coefficient is explained by the fact that it characterizes the enterprise development strategy, including orientation of his credit policy (production sales markets expansion or market share preservation).

We appropriated to coefficient of a ratio of the company receivables 'average size and the money invested in receivables possible $\operatorname{limit}\left(K_{3}\right)$ and also receivables and payables ratio coefficient $\left(K_{5}\right)$ identical importance authorities -0.2 . It is explained by the fact that both coefficients reveal an enterprise work with contractors for return of the debt efficiency which has arisen at them for the considered company.

We appropriated to indicators of growth rate of receivables $\left(K_{2}\right)$ and uncollectible debt proportion as a part of debit $\left(K_{4}\right)$ the authorities of the importance 0.2 and 0.1 respectively. Values of scales is explained by the fact that coefficients characterize only corporation receivables dynamics and structure. 
Thus, having defined authorities for each indicator included into the first group, we can enter (introduce) an intermediate integrated receivables management quality indicator $\left(X_{1}\right)$ (formula 1$)$ :

$$
\begin{aligned}
& X_{1}=0.3 \times K_{1}+0.2 \times K_{2}+0.2 \times K_{3}+ \\
& 0.1 \times K_{4}+0.2 \times K_{5},
\end{aligned}
$$

where: $X_{1}-$ an intermediate integrated receivables management quality indicator.

From the second group indicators we will appropriate the largest authority to coefficient of a ratio of the actual and planned amount of money, invested in receivables $\left(K_{8}\right)-0.5$. The high importance of this indicator is due to the fact that it allows to estimate the credit policy from the point of view of the company purpose achievement on the product sales volume and consequently, also of the receivables management effectiveness.

To current assets derivation in receivables coefficient we will determine the authority at the level of 0.3. This is due to this coefficient enables to analyse whether the credit policy corresponds to the chosen enterprise direction in the field of contractors crediting.

To overdue receivables coefficient $\left(K_{6}\right)$, we determined authority at the level of 0.2 . This indicator helps to define, whether the contractors solvency assessment standards and also efficiency of the measures applied for the uncollectible debt emergence and increase in an overdue share prevention purpose are correctly developed by the enterprise.

Thus, having defined authorities for the second group indicators, we can introduce an intermediate integrated receivables service efficiency indicator (formula 2):

$$
X_{2}=0.2 \times K_{6}+0.3 \times K_{7}+0.5 \times K_{8},
$$

where: $X_{2}$ - an intermediate integrated receivables service efficiency indicator.

From the third group indicators we appropriated the largest authority to coefficient of sales profitability $\left(K_{12}\right)-0.2$. The high importance of coefficient in indicators group is explained by the fact that it most precisely allows to define influence of the chosen credit policy type on such financial condition indicators as the gross profit and production sales income.

To such indicators as urgent $\left(K_{9}\right)$ and current $\left(K_{10}\right)$ liquidity coefficients, growth rate of sales proceeds $K_{11}$ ), coefficient of cash to sales ratio $\left(K_{14}\right)$ we determined authorities at the level of 0.15 . Such level of coefficients importance is explained by the fact that indicators characterize the enterprise credit policy influence on various financial aspects of the company activity: solvency in the short and medium term, production sales income, the cash funds and funds on accounts of the organization.

We appropriated to funds turnover coefficient $\left(K_{13}\right)$ and payables turnover coefficient $\left(K_{15}\right)$ authorities at the level of 0.1 . These indicators give an assessment of indirect influence of credit policy on turnover of accounts payable and money. Need of their calculation for the enterprise consists in the analysis of enterprise credit policy type and terms correctness.

Having defined importance authorities for indicators of the third group, we can introduce an intermediate integrated indicator of influence on a financial condition (formula 3 ):

$$
\begin{aligned}
& X_{3}=0.15 \times K_{9}+0.15 \times K_{10}+0.15 \times K_{11}+0.2 \times \\
& K_{12}+0.1 \times K_{13}+0.15 \times K_{14}+0.1 \times K_{15},
\end{aligned}
$$

where: $X_{3}$ - an intermediate integrated indicator of influence on the enterprise financial condition.

At the following stage of model forming the importance of an intermediate integrated indicator by group $\left(X_{\mathrm{i}}\right)$ was determined according to author's expert evaluation depending on type of credit policy.

For the corporations adhering to aggressive (soft) type of credit policy the first group indicators will be most significant. Therefore we appropriated its authority in our model at the level of 0.6.

The following on the importance will be the second indicators group. So the authority of the coefficients connected with service of receivables will be appropriated at the level of 0.4. At aggressive type of credit policy the purpose of the enterprise is growth of sales, and influence on indicators of a financial state is of secondary importance therefore the third group indicators authority in model will be appropriated at the level of 0.1 .

For the corporations adhering to moderate credit policy type the first group indicators will also be the most significant. Therefore its authority will be appropriated at the level of 0.4 . The purpose of the enterprise applying moderate credit policy type is the moderate sales growth and also improvement of receivables quality, its reduction. Therefore indicators of the second and third group will have identical authorities -0.3 .

For the corporations adhering to conservative (rigid) type of credit policy indicators of financial condition will be most significant. Therefore we appropriated the third coefficients group authority at the level of 0.7 . 
The following on the importance will be the coefficients connected with receivables service. Therefore the second group of indicators will have authority 0.2 . At conservative credit policy type the receivables management quality indicators will be of secondary importance, their authority will be 0.1 .

Thus, integrated efficiency assessment indicators depending on a type of credit policy $\left(\mathrm{I}_{\mathrm{j}}\right)$ it will be calculated by a formula 4 :

$$
I_{j}=\sum A_{i} \times X_{i},
$$

where: $A_{i}$ - an authority of an intermediate integrated indicator on group depending on credit policy type; $X_{i}$ - value of an intermediate integrated indicator on group.

The developed model for carrying out the overall credit policy efficiency assessment analysis is given in Table 1.
For the purpose of model development for carrying out the express credit policy efficiency assessment we have selected one indicator from each group considered above. The authorities of intermediate integrated indicators $\left(X_{i}\right)$ for each of groups we left at the same level, as well as in model of the overall credit policy efficiency analysis, authorities will also be splitted depending on the realized corporation contractor's credit policy type.

The developed model for carrying out the express credit policy efficiency assessment is given in Table 2.

At the following stage of creation of model it is required to determine standard values for intermediate indicators by group and integrated indicators in models full and the express analysis of assessment of credit policy. We will use for this purpose the standard values characteristic of the indicators chosen and included in our model. Their size is specified in Table 3 .

Table 1. The developed model of the overall efficiency credit policy assessment

\begin{tabular}{|c|c|c|c|c|c|}
\hline \multirow{2}{*}{$\begin{array}{l}\text { Name of } \\
\text { an indica- } \\
\text { tor }\end{array}$} & \multirow{2}{*}{$\begin{array}{l}\text { Indicator } \\
\text { author- } \\
\text { ity }\left(a_{i}\right)\end{array}$} & \multirow{2}{*}{$\begin{array}{l}\text { Value of an in- } \\
\text { termediate inte- } \\
\text { grated indicator } \\
\text { on group }(X i)\end{array}$} & \multicolumn{3}{|c|}{$\begin{array}{c}\text { The authority of an intermediate integrated indicator on group } \\
\text { depending on type of credit policy }\left(A_{i}\right)\end{array}$} \\
\hline & & & Aggressive type & Moderate type & Conservative type \\
\hline \multicolumn{6}{|c|}{ Group I - The enterprise receivables management quality indicators } \\
\hline K1 & 0.3 & \multirow{5}{*}{$X_{1}=\sum a_{i} \times K_{i}$} & \multirow{5}{*}{0.6} & \multirow{5}{*}{0.4} & \multirow{5}{*}{0.1} \\
\hline К2 & 0.2 & & & & \\
\hline К3 & 0.2 & & & & \\
\hline K4 & 0.1 & & & & \\
\hline K5 & 0.2 & & & & \\
\hline \multicolumn{6}{|c|}{ Group II - The indicators connected with service of receivables } \\
\hline K6 & 0.2 & \multirow{3}{*}{$X_{2}=\sum a_{i} \times K_{i}$} & \multirow{3}{*}{0.3} & \multirow{3}{*}{0.3} & \multirow{3}{*}{0.2} \\
\hline К7 & 0.3 & & & & \\
\hline K8 & 0.5 & & & & \\
\hline \multicolumn{6}{|c|}{ Group III - The indicators reflecting influence on the enterprise financial condition } \\
\hline K9 & 0.15 & \multirow{7}{*}{$X_{3}=\sum a_{i} \times K_{i}$} & \multirow{7}{*}{0.1} & \multirow{7}{*}{0.3} & \multirow{7}{*}{0.7} \\
\hline K10 & 0.15 & & & & \\
\hline K11 & 0.15 & & & & \\
\hline K12 & 0.2 & & & & \\
\hline K13 & 0.1 & & & & \\
\hline K14 & 0.15 & & & & \\
\hline K15 & 0.1 & & & & \\
\hline $\begin{array}{l}\text { Integrated } \\
\text { indicator } \\
(I j)\end{array}$ & - & - & $I_{1}=\sum A_{i} \times X_{i}$ & $I_{2}=\sum A_{i} \times X_{i}$ & $I_{3}=\sum A_{i} \times X_{i}$ \\
\hline
\end{tabular}


Table 2. The offered model for carrying out the express corporation credit policy efficiency assessment

\begin{tabular}{|c|c|c|c|c|}
\hline \multirow{2}{*}{ Name of an indicator } & $\begin{array}{c}\text { Value of an interme- } \\
\text { diate integrated indi- } \\
\text { cator on group }\end{array}$ & $\begin{array}{r}\text { The authority of an intermediate integrated indicator on group de- } \\
\text { pending on type of credit policy (Ai) }\end{array}$ \\
\cline { 3 - 5 } & $\begin{array}{r}\text { Aggressive type } \\
\text { Moderate type }\end{array}$ & Conservative type \\
\hline Group I - The enterprise receivables management quality indicators \\
\hline K1 & $X_{1}$ & 0.6 & 0.4 & 0.1 \\
\hline Group II - The indicators connected with service of receivables & 0.3 & 0.2 \\
\hline K8 & $X_{2}$ & 0.3 & 0.3 & 0.7 \\
\hline Group III - The indicators reflecting influence on the enterprise financial condition \\
\hline K12
\end{tabular}

Table 3. Standard values for integrated indicators of assessment efficiency on group and integrated indicators depending on type of credit policy

\begin{tabular}{|c|c|c|c|c|c|c|c|c|c|}
\hline \multirow{2}{*}{$\begin{array}{l}\text { Name } \\
\text { of an } \\
\text { indica- } \\
\text { tor }\end{array}$} & \multirow{2}{*}{$\begin{array}{l}\text { Standard } \\
\text { group indi- } \\
\text { cator value }\end{array}$} & \multirow{2}{*}{$\begin{array}{l}\text { Indica- } \\
\text { tor au- } \\
\text { thority } \\
\text { in } \\
\text { group }\end{array}$} & \multirow{2}{*}{$\begin{array}{l}\text { Standard } \\
\text { value of an } \\
\text { intermedi- } \\
\text { ate inte- } \\
\text { grated indi- } \\
\text { cator on } \\
\text { group }\left(X_{i}\right)\end{array}$} & \multicolumn{3}{|c|}{$\begin{array}{l}\text { The authority of an inter- } \\
\text { mediate integrated indica- } \\
\text { tor on group depending on } \\
\text { type of credit policy }\left(\mathrm{A}_{\mathrm{i}}\right)\end{array}$} & \multicolumn{3}{|c|}{$\begin{array}{c}\text { Standard value of an inte- } \\
\text { grated indicator in depend- } \\
\text { ence on type of credit policy } \\
\left(I_{i}\right)\end{array}$} \\
\hline & & & & $\begin{array}{l}\text { Ag- } \\
\text { gres- } \\
\text { sive } \\
\text { type }\end{array}$ & $\begin{array}{l}\text { Mod- } \\
\text { erate } \\
\text { type }\end{array}$ & $\begin{array}{l}\text { Con- } \\
\text { serva- } \\
\text { tive } \\
\text { type }\end{array}$ & $\begin{array}{l}\text { Ag- } \\
\text { gres- } \\
\text { sive } \\
\text { type }\end{array}$ & $\begin{array}{l}\text { Mod- } \\
\text { erate } \\
\text { type }\end{array}$ & $\begin{array}{l}\text { Conserva- } \\
\text { tive type }\end{array}$ \\
\hline \multicolumn{10}{|c|}{ Group I - The enterprise receivables management quality indicators } \\
\hline$K_{1}$ & $>1$ & 0.3 & \multirow{5}{*}{$X_{1} \geq 1.02$} & \multirow{5}{*}{0.6} & \multirow{5}{*}{0.4} & \multirow{5}{*}{0.1} & \multirow{17}{*}{$\begin{array}{l}I_{1} \geq \\
0.90\end{array}$} & \multirow{17}{*}{$\begin{array}{l}I_{2} \geq \\
0.87\end{array}$} & \multirow{17}{*}{$I_{3} \geq 0.85$} \\
\hline$K_{2}$ & $\leq 1.5$ & 0.2 & & & & & & & \\
\hline$K_{3}$ & $\leq 1$ & 0.2 & & & & & & & \\
\hline$K_{4}$ & $\leq 0.15$ & 0.1 & & & & & & & \\
\hline$K_{5}$ & $0.9-1$ & 0.2 & & & & & & & \\
\hline & up II - The i & licators & nnected witl & ervice & eceival & & & & \\
\hline$K_{6}$ & $\leq 0.20$ & 0.2 & \multirow{3}{*}{$X_{2} \geq 0.66$} & \multirow{3}{*}{0.3} & \multirow{3}{*}{0.3} & \multirow{3}{*}{0.2} & & & \\
\hline$K_{7}$ & $0.2-0.3$ & 0.3 & & & & & & & \\
\hline$K_{8}$ & $>1$ & 0.5 & & & & & & & \\
\hline \multicolumn{7}{|c|}{$\begin{array}{c}\text { Group III - The indicators reflecting influence on the enterprise financial } \\
\text { condition }\end{array}$} & & & \\
\hline$K_{9}$ & $0.7-1$ & 0.15 & \multirow{7}{*}{$X_{3} \geq 0.88$} & \multirow{7}{*}{0.1} & \multirow{7}{*}{0.3} & \multirow{7}{*}{0.7} & & & \\
\hline$K_{10}$ & $1.5-2.5$ & 0.15 & & & & & & & \\
\hline$K_{11}$ & $>1$ & 0.15 & & & & & & & \\
\hline$K_{12}$ & $\begin{array}{l}>0, \text { for ex- } \\
\text { ample, for } \\
\text { petroleum } \\
\text { industry - } \\
\quad 0.26\end{array}$ & 0.2 & & & & & & & \\
\hline$K_{13}$ & - & 0.1 & & & & & & & \\
\hline$K_{14}$ & aspires to 1 & 0.15 & & & & & & & \\
\hline$K_{15}$ & $>1$ & 0.1 & & & & & & & \\
\hline
\end{tabular}


Using authorities and standard values of indicators in each group, we will calculate standard value of an intermediate integrated indicator for each group $\left(X_{i}\right)$. Standard values are accepted in accordance with Russian practice

For determination of the first group integrated indicator standard value $\left(X_{1}\right)$ we substituted in a formula of calculation $X_{1}$ of value of the indicators corresponding to their standard level (formula 5):

$$
\begin{aligned}
& X_{1 \text { norm }}=0.3 \times 1.05+0.2 \times 1.5+0.2 \times \\
& 0.95+0.1 \times 0.15+0.2 \times 1=1.02 .
\end{aligned}
$$

At $X_{1} \geq 1.02$ credit policy the enterprise realized will be considered as effective. At $X_{1}<1.02$ credit policy realized by the enterprise will be estimated as inefficient.

We determined the second group integrated indicator standard value $\left(X_{2}\right)$ according to the formula 6:

$$
\begin{aligned}
& X_{2 \text { norm }}=0.2 \times 0.2+0.3 \times 0.3+ \\
& 0.5 \times 1.05=0.66 .
\end{aligned}
$$

At $X_{2} \geq 0,66$ credit policy realized by the enterprise will be admitted as effective.

At $X_{2}<0.66$ credit policy realized by the enterprise will be admitted as inefficient.

We determined the third group integrated indicator standard value $\left(X_{3}\right)$ according to the formula 7:

$$
\begin{aligned}
& X_{3 \text { norm }}=0.15 \times 0.7+0.15 \times 1.5+0.15 \times \\
& 1.05+0.2 \times 0.26+0.1 \times 1+0.15 \times 0.9+ \\
& 0.1 \times 1.05=0.88 .
\end{aligned}
$$

At $X_{3} \geq 0.88$ credit policy realized by the enterprise will be considered as effective.

At $X_{3}<0.88$ credit policy realized by the enterprise will be considered as inefficient.

We will carry out similar calculation for determination of standard values of integrated indicators for each type of credit policy $\left(I_{j}\right)$.

Standard value of an integrated indicator for aggressive credit policy (8):

$$
\begin{aligned}
& I_{1 \text { norm }}=1.02 \times 0.6+0.66 \times 0.3+ \\
& 0.88 \times 0.1=0.9 .
\end{aligned}
$$

Standard value of an integrated indicator for moderate credit policy (9):

$$
\begin{aligned}
& I_{2 \text { norm }}=1.02 \times 0.4+0.66 \times 0.3+ \\
& 0.88 \times 0.3=0.87 .
\end{aligned}
$$

Standard value of an integrated indicator for conservative credit policy:

$$
\begin{aligned}
& I_{3 \text { norm }}=1.02 \times 0.1+0.66 \times 0.2+ \\
& 0.88 \times 0.7=0.85 .
\end{aligned}
$$

Thus, if the corporation adheres to aggressive (soft) credit policy type, then the credit policy will be considered as effective at integrated indicator value $I_{1} \geq 0.9$.

If the corporation adheres to moderate credit policy type, then the credit policy will be considered as effective at integrated indicator value $I_{2} \geq 0.87$.

If the corporation adheres to conservative (rigid) type of credit policy, then the company contractors crediting policy will be considered as effective at integrated indicator value $I_{3} \geq 0.85$.

\section{Conclusions}

Thus, in the presented work:

- two analytical systems including indicators for carrying out overall and express credit policy efficiency analysis are created, each of which includes three groups of indicators characterizing:
a) receivables management quality;
b) costs of its service;
c) its influence on the corporation finan- cial condition.

Applying these systems will allow to realize the complexity and focus principles that will facilitate to reveal problem zones as a result of credit policy efficiency assessment;

- the technique of integrated corporation credit policy efficiency assessment is developed. It includes calculation of individual, group and integrated indicators system taking into account the different authorities of indicators groups for corporation at various credit policy types that allows to consider in the analysis the purposes and tasks of receivables management.

\section{References}

Aristarkhova, M. A. (2016). Increase of the enterprise accounts receivable management efficiency by forming the management simulation model. Oil and Gas Business, (5), 6-12.

Arutyunyan, G. A., \& Borisov, D. V. (2015). Theory and practice of forming a credit policy in a modern organization. The Economy of Development, (4), 21-28.

Białek-Jaworska, A., \& Nehrebecka, N. (2016). The role of trade credit in business operations. Argumenta Oeconomica, 37(2), 189-231.

Dincǎ, M. S., \& Dincă, G. (2013). The use of commercial credit policy to increase the company value. Journal of Applied Economic Sciences, 8(2), 165-173. 
Duft, K. (2006). Accounts receivable analysis and the assessment of credit policy changes. Retrieved from http://www.agribusiness-mgmt.wsu.edu/Extension Newsletters/PriceCost.htm

Galaktionova, A. A. (2015). Formation of the credit policy of the oil refining industry. A. A. Galaktionova, L. V. Podobedova. RBC. Business Journal, (3). Retrieved from http://edrussia.ru

Gerasimova, L. N. (2012). Investigation of accounts receivable analysis methods in order to improve its quality. Economic Sciences, (9), 15-24.

Huang, Y.-F., \& Goyal, S. K. Retailer's replenishment policy under supplier credit linked to payment time. International Journal of Information and Management Sciences, 18(1), 49-62.

Isachenko, M. B. (2014). Management of accounts receivable and development of the company's credit policy. Advances in Modern Natural Science, (12), 123-126.

Kim, J., Hwang, H., \& Shinn, S. (1995). An optimal credit policy to increase supplier's profits with price dependent demand functions. Production Planning and Control, 6(1), 45-50. https://doi.org/10.1080/09537289508930252

Kisileva, I. T. (2013). Controlling as a tool for managing receivables and payables. Tax Accounting for an Accountant, (15), 25-29.

Kuznetsova, N. G. (2014). Credit policy in the system of corporate financing. Finance and Credit, (5), 4-9.

Li, R., Skouri, K., Teng, J.-T., \& Yang, W.-G. (2018). Seller's optimal replenishment policy and payment term among advance, cash, and credit payments. International Journal of Production Economics, 197(2018, March), 35-42. https://doi.org/10.1016/j.ijpe.2017.12.015

Lipchenko, N. V. (2014). Formation of the credit policy of the oil refining industry enterprise. In N. V. Lipchenko \& K. S. Balovneva. Russian Entrepreneurship, No. 9 [Electronic resource]. Retrieved from http://old.creativeconomy.ru

Lukyanova, A. E, \& Nikulin, E. D. (2008). Credit policy as a tool for managing the organization's receivables. Bulletin of St. Petersburg State University, Ser. 8(1) [Electronic resource]. Retrieved from https://cyberleninka.ru/article/v/kreditnaya-politika-kak-instrument-upravleniya-debitorskoy-zadolzhennostyu-organizatsii-1

Mahata, P., \& Mahata, G. C. (2014). Economic production quantity model with trade credit financing and pricediscount offer for non-decreasing time varying demand pattern. International Journal of Procurement Management, 7(5), 563-581. https://doi.org/10.1504/IJPM.2014.064619

Martínez-Sola, C., García-Teruel, P. J., \& Martínez-Solano, P. (2013). Trade credit policy and firm value. Accounting and Finance, 53(3), 791-808. https://doi.org/10.1111/j.1467-629X.2012.00488.x
Mityushnikova, Yu. S., Rudneva, Yu. R., \& Gareeva, Z. A. (2017). Investigation of the dependence of the enterprise's credit policy type on external and internal factors. European Journal of Law, (5), 369-371.

Nechaev, V. I., \& Gerasimova, L. N. (2013). Improvement of the accounts receivable cash analysis methods to reduce the enterprise financial risks. Audit and Financial Analysis, (2), 18-27.

Nikolaev, I. A. (2015). Internal control system of the enterprise accounts receivable management. The Financial Director, (4), 44-54.

Nikolaev, I. N. (2012). What to take into account when developing a credit policy. Financial Director, (2), 32-43.

Oh, S., \& Kim, W. S. (2016). Growth opportunities and trade credit: evidence from Chinese listed firms. Applied Economics, 48(56), 5437-5447. https://doi.org/10.1080/00036846.2016.1178846

Prudnikov, A. K. (2014). Accounts receivable management as a tool for effective working capital management. $\mathrm{Fi}$ nancial Director, (8), 114-124.

Sanovich, M. A. (2013). Justification of the need to change the credit policy of the enterprise in order to improve its activities efficiency. Electronic Journal, (11). Retrieved from http://nauka-rastudent.ru

Sidorov, G. R. (2013). ABC and scenario analysis of receivables. Finance and Credit, (9), 14-19.

Sokolova, N. A. (2014). Accounts receivable analysis and management in a financial crisis. Financial Analysis, (17), 35-39.

Tavis, L. A. (1970). Finding the best credit policy. A model for studying the components. Business Horizons, 13(5), 33-40. https://doi.org/10.1016/0007-6813(70)90110-2

Trenev, N. N. (2015). Accounts receivable management as a way of increasing enterprise financial results. Financial Director, (3), 56-65.

Tunčikienè, Ž., \& Drejeris, R. (2015). Entrepreneur-ship ecosystem: methodological approaches to functions' review of public sector institutions. Entrepreneurship and Sustainability Issues, 2(3), 118-132. https://doi.org/10.9770/jesi.2014.2.3(1)

Volnin, V. A. (2011). Enterprise credit policy: transition to system management. Financial Bulletin: Finances, Taxes, Insurance, Accounting, (8), 5-14.

Volostnova, V. A. (2015). Working out the debt receivable management strategy. The Bulletin of the Perm University, (3), 26-39.

Zimin, N. E. (2014). The enterprise credit policy improvement through accounts receivable management. Economic Journal of the Higher School of Economics, (6), 15-20.

Zotkov, O. M. (2012). Credit policy optimization in order to ensure the enterprise profitability and financial stability balance. Russian Entrepreneurship/ (5), 34-45. 